\title{
Private consumption as a factor to engage human capacity in terms of sustainable development
}

\author{
Elena Rozhdestvenskaia ${ }^{1,2, *}$ \\ ${ }^{1}$ Tomsk State University, Lenina Str., 36, 634050 Tomsk, Russia \\ ${ }^{2}$ Tomsk Polytechnic University, Lenina Str., 30, 634050 Tomsk, Russia
}

\begin{abstract}
Investigated private consumption as a substantial factor to accumulate human potential. Author has revealed the function of private consumption as a tool to reproduce human capital. To restruct of private consumption towards a shift towards the prevalence of disposable income towards the consumption of "knowledge-intensive" goods and services is a factor for sustainable development of the Russian economy. A hypothesis put forward that creative consumption determines the sustainability of the development of society.
\end{abstract}

\section{Introduction}

The theory of sustainable development casts doubt on the idea of "homo oeconomicus", who motivated only by rational interest. Now, a person is presented as the creator and beneficiary of the sustainable development system in terms of the current and future generations development. In this context, changing the motives of personal consumption fulfills the reproductive function of human capital of a new property. Such a system is the fundamental basis for the concept of sustainable development with an emphasis on the social and environmental motives of private consumption. Purely economic motivators for consumption distort the value picture and inhibit sustainable development. The paradigm of economic research is shifting towards an interdisciplinary approach to scientific research, scientists widely include social and cultural aspects even economists. The utilitarian logic of consumption is criticized [1], a person is considered as "irrational", the philosophy of a "rational" person in the postmodern marketing paradigm is becoming a fossil thing. The modern concept of economic thought proceeds from the premise of impossibility to convert social and environmental values into a purely economic field, the value created is a continuum of its three components. Consumption performs not only the function of reproduction of human capital, but also of its development [2]. From a theoretical point of view, new marketing concepts emerged with a change in consumer status in a postmodern context, which highlights the shift in power from sellers to buyers and the emergence of a "new consumer" [3].

\footnotetext{
* Corresponding author: elena.rojdestvenskaya@gmail.com
} 
We could depict the cultural base and a certain set of values associated with the development of the individual creativity and "glocalization". To move beyond the dominant utilitarian logic still used in economic research (in Russian as well), economists should pay attention to related research in other areas [4], which are raised the question of humanitarian doctrine and the primacy of creation for a long time.

Consumer behavior economic studies react to a new socio-humanitarian paradigm, for example, the implementation of the consumer culture approach, founded by Arnould and Thompson since 2005 [5]. This approach presents a new revolution in scientific problems in the sphere of consumption. The basic idea is the individual behaves and consumes for a specific purpose [6] in the time frame, living his actions as a personal experience or as a general game [7]. Consequently, consumer behavior cannot be understood without taking into account all aspects of his life and work [8], such as ideological, social, cultural, symbolic and empirical consumption in its context [3].

The research hypothesis determines by the postulates of the evolutionary theory of economics, which assumes the premise of the personal consumption relationship (more precisely, the expenditures structure) as an indicator to measure development of the knowledge economy subsystem.

The purpose of this article is to provide a theoretical basis for the assumption of a change in the reproductive function of creative consumption as a factor in the sustainable development of society.

\section{Research Methods and Consumption Functions}

Methods of analysis existing concepts of consumption by foreign and Russian scientists have used at the stage of identifying the main functions of "private consumption" in the context of goal-oriented development, based on the principles of sustainability; a content analysis carried out the citied databases Web of Knowledge, Elibrary, Google Scholar. An approach mastermind to determine the functions of private consumption and the concept of changing emphasizes in the context of digitalization and labor creation by synthesis individual components.

The trend for co-production and consumption is highlighted on the basis of consumer experience, which is dictated by the property of accumulating intellectual capital $[9,10]$. Author notices an increase in consumer opportunities, which dictated by the use of the Internet to search for information, organize joint purchases and supply chains [11]. Google trends using as a tool to predict consumer behavior $[12,13]$.

Premise the basic concepts of consumption on a sociocultural position, focusing on changing consumer preferences towards active inclusion in the process, the economy of experience [14], and expanding the function of consumption from reproductive, regulating and stimulating to the development of personality and individuality.

Thus, the process of consumption includes the acquisition of some kind of consumer experience in a significant part, which makes the consumer a creator and co-producer of the value. We should talk about the trend to redact material private consumption with the development of the subsystem of production and consumption of "knowledge, impressions and experience" [15].

To test proposed method, author has analyzed the structure of private consumption of the leading world economies (USA, Germany and Japan) and Russia. The key arrangement to select this national economy is the indicator of material consumption by households in million tons over the past at least five years, according to PASSPORT EUROMONITOR.

A groundwork has formed to create an assessment tool for monitoring indirect indicators and development of the national economy subsystem, which focused on the implementation 
of sustainable development goals and the actual transition to the path of "post-industrial" development.

The hypothesis has tested on regional data from a sociological poll in the Tomsk region among the population over 50 years old, which is carried out annually by the International Scientific and Educational Laboratory of Technologies for Improving the Well-Being of Elderly People at the Tomsk Polytechnic University (hereinafter - LifeLong Wellbeing Lab TPU). The purpose of this sociological inquest is to assess the implementation of resource potential, attitudes towards employment and social activity of people of pre-retirement and retirement age. The research carried out within the framework of the project No. 19-18-00300 of the Russian Science Foundation "Institutions to unlock the untapped resource potential of the older generation in an aging economy". The paper analyzes the data obtained during sociological surveys in July 2019 (sample 450, 50+) and in July 2020 (sample 600, 50+).

\section{Private Consumption as a Factor to Engage Human Capacity}

Paradigm of the "materialistic value system" prevailing in Russian economic assessments of human potential. Some papers separate the production and consumption of economic value from social and environmental, but an attempt is made to reduce everything to a quantitative assessment and "reification" of traditionally immaterial forms that do not lend themselves to market assessment - aspirations for self-improvement and personal development, individualization and lifelong learning, allocation new knowledge, etc. Some scientists attempt to measure economically new motives and values that drive consumers, prompting a transformation in the production.

The digitalization of routine processes releases not only low-skilled physical labor (typical of the period of industrialization and mass-market), but at the current stage of development of technology and technology, low-skilled intellectual work is automated, discussions about dying professions are widespread, which include "journalists, accountants, notaries , statistics, etc. " (See: Atlas of new professions 3.0 / M: Intellectual literature. 2020. - $456 \mathrm{p}$ [electronic resource]. URL: http://atlas100.ru/).

Changing the labor function is the main prerequisite for changing the nature of consumption towards the demand for the reproduction of intellectual resources lifelong learning and the use untapped personal potential. Reproduction of highly intellectual labor is impossible without appropriate investments in the development and realization of human capacity. To invest in human capital and in the 'intellectualization' of the labor force are growing both on the part of the state and on the part of individuals. Changes the structure and nature of private consumption, adapting to the labor market demand. At the macro level, systems allow the acquisition and application of new knowledge, ensuring the diffusion of fundamental, applied and experimental knowledge. At the micro level, modern tendencies notice to overcome economic motivation through self-development and continuous improvement of the intellectual level as a condition for ensuring competitiveness in the computerized labor market.

Investments in intellectual capital, an individual approach to the upbringing of each child give an increase to the national human potential [16]. The quality of young human potential largely depends on the level and quality of parent's life and family members through the mechanism of inheritance of intellectual and social resources. In Russia, there is a low private capacity to invest in education and health care for children and families in general. According to Rosstat, in Russia in 2018, on average, the purchase of food products occupies $33.5 \%$ of the structure of expenditures on private consumption (33\% of the Tomsk region), $37 \%$ of the purchase of non-food products ( $36.7 \%$ of the Tomsk region), i.e. more than $70 \%$ of household income goes to material consumption. We can say that in Russia the society of mass consumption dominates, based on the analysis of the structure of private consumption, the 
main motive is to cover the basic needs of the family (See Table 1). Investments in the service sector have underfunded, low incomes and their high differentiation create obstacles to diversification of private consumption in accordance with the goals of sustainable development of the Russian economy. Thus, the task of investing in the formation of children's intellectual capital goes beyond the household level as a priority task of the national economy.

Table 1. Types of society depending on changes in the consumption function

\begin{tabular}{|l|l|l|l|}
\hline $\begin{array}{l}\text { Types of } \\
\text { society }\end{array}$ & $\begin{array}{l}\text { Society for basic } \\
\text { goods consumption }\end{array}$ & $\begin{array}{l}\text { Society for mass- } \\
\text { market }\end{array}$ & $\begin{array}{l}\text { Society for co-creation } \\
\text { consumption }\end{array}$ \\
\hline $\begin{array}{l}\text { Consumption } \\
\text { properties }\end{array}$ & Vital needs prevail & $\begin{array}{l}\text { Standard set of } \\
\text { material needs }\end{array}$ & $\begin{array}{l}\text { Quantitative and qualitative } \\
\text { growth of intangible needs }\end{array}$ \\
\hline $\begin{array}{l}\text { Consumption } \\
\text { process }\end{array}$ & $\begin{array}{l}\text { Dominant motives of } \\
\text { survival, social norms } \\
\text { and traditions, } \\
\text { physiological needs }\end{array}$ & $\begin{array}{l}\text { Dominant economic } \\
\text { motives for } \\
\text { providing a standard } \\
\text { set of material } \\
\text { goods }\end{array}$ & $\begin{array}{l}\text { Dominant the motives of } \\
\text { self-realization, freedom } \\
\text { and individuality, } \\
\text { personality development }\end{array}$ \\
\hline $\begin{array}{l}\text { Consumption } \\
\text { system }\end{array}$ & Base consumption & Mass consumption & Experience consumption \\
\hline
\end{tabular}

Source: compiled by the author based on [17]

Underfunding the demand for final consumption expenditures (HFCE) of services in education and health care predetermines the limited possibilities for their production and quality improvement, which ultimately affects the accumulation of the country's human potential. In the countries of developed capitalism, the inverse proportion of material and non-material final consumption prevails. As can be seen from the data in Table 2, countries with a developed subsystem of the knowledge economy (USA, Germany, Japan) are in 20 countries in terms of material consumption of households, but there is an obvious tendency to reduce material consumption in million tons. While the countries of extensive development of industrial-type capitalism (China, India, Russia, etc.) are increasing the volume of material consumption. The global tendency of increasing material consumption is seen as dangerous, which signals the development of the process of formation of a society of mass consumption in most countries, as opposed to countries of post-industrial development, of which the minority. The structure of personal consumption and the share of the material component in the volume of final consumption of households can become an indicator, albeit indirect, of the development of the knowledge economy subsystem and the post-industrial development of the national economy as a whole. In this vein, the pandemic has a positive effect on the transformation of the structure of personal consumption into a priority of private investment in self-development and the acquisition of new knowledge and skills.

Table 2. Material consumption of households, million tons

\begin{tabular}{|r|l|r|r|r|r|r|r|}
\hline \multicolumn{1}{|c|}{ № } & Geography & \multicolumn{1}{l|}{$\mathbf{2 0 1 4}$} & \multicolumn{1}{l|}{$\mathbf{2 0 1 5}$} & \multicolumn{1}{l|}{$\mathbf{2 0 1 6}$} & \multicolumn{1}{l|}{$\mathbf{2 0 1 7}$} & \multicolumn{1}{l|}{$\mathbf{2 0 1 8}$} & \multicolumn{1}{l|}{$\mathbf{2 0 1 9}$} \\
\hline 1 & China & 31517 & 32454 & 33780 & 35101 & 36097 & 37109 \\
\hline 2 & India & 6806 & 6985 & 7194 & 7403 & 7569 & 7731 \\
\hline 3 & USA & 6488 & 6340 & 6187 & 6036 & 5911 & 5791 \\
\hline 4 & Brazil & 2459 & 2533 & 2606 & 2680 & 2741 & 2799 \\
\hline 5 & Russia & 2227 & 2272 & 2309 & 2347 & 2377 & 2406 \\
\hline 6 & Indonesia & 1767 & 1850 & 1913 & 1973 & 2024 & 2072 \\
\hline 7 & Germany & 1363 & 1278 & 1294 & 1308 & 1308 & 1317 \\
\hline 8 & Iran & 1079 & 1117 & 1144 & 1172 & 1197 & 1220 \\
\hline 9 & Vietnam & 881 & 942 & 996 & 1050 & 1096 & 1139 \\
\hline
\end{tabular}


Table 2. Continued

\begin{tabular}{|r|l|r|r|r|r|r|r|}
\hline 10 & Japan & 1213 & 1185 & 1163 & 1140 & 1121 & 1103 \\
\hline 11 & Turkey & 936 & 1007 & 1026 & 1047 & 1078 & 1098 \\
\hline 12 & Canada & 1046 & 1043 & 1049 & 1055 & 1060 & 1064 \\
\hline 13 & Mexico & 990 & 1001 & 1017 & 1034 & 1046 & 1059 \\
\hline 14 & Australia & 912 & 920 & 924 & 927 & 931 & 934 \\
\hline 15 & Thailand & 818 & 836 & 858 & 879 & 896 & 913 \\
\hline 16 & Pakistan & 815 & 837 & 857 & 876 & 892 & 907 \\
\hline 17 & Saudi Arabia & 706 & 758 & 790 & 822 & 855 & 881 \\
\hline 18 & Egypt & 655 & 695 & 729 & 766 & 795 & 823 \\
\hline 19 & Poland & 654 & 643 & 672 & 712 & 773 & 807 \\
\hline 20 & France & 777 & 740 & 725 & 781 & 787 & 800 \\
\hline
\end{tabular}

Source: Domestic Material Consumption: Euromonitor International from Eurostat, WU Global Material Flows Database https:/www-portal-euromonitorcom.ez.lib.tsu.ru/portal/statisticsevolution/index (2020)

Values have changed in the conditions of self-isolation and the restrictive measures in 2020, especially among older people. We could conclude a change (or rather, an emerging trend) in shared social values and social installations based on the data of LifeLong Wellbeing TPU sociological research hold in the Tomsk region to understand the institutions for untapped region resource potential in the context of an aging economy (July 2019 to July 2020 , sample of $450 / 600$ people $50+$ ).

Research shows that there are "traditional static and dynamic aspects of the consciousness of the elderly" [18]. The dynamics manifests in the fact that the weight of some variables changes while maintaining the significance of other social attitudes. At the change of epochs, changes are noticeable even in the core of values - due to the effect of time - of global transformations in society. Therefore, in Soviet times, the value core of pensioners included such values as "family, children, and grandchildren" (1 rank), "labor, work in production" (2), "good health" (3)

\section{WHAT IS MOST IMPORTANT TO YOU NOW?}

Wellbeing of relatives and closed people
Good health
Conversation (meeting with friends etc.)
State care for the elderly
Material wealth
Good housing
Active life position
Interesting job
Other
Find it difficult

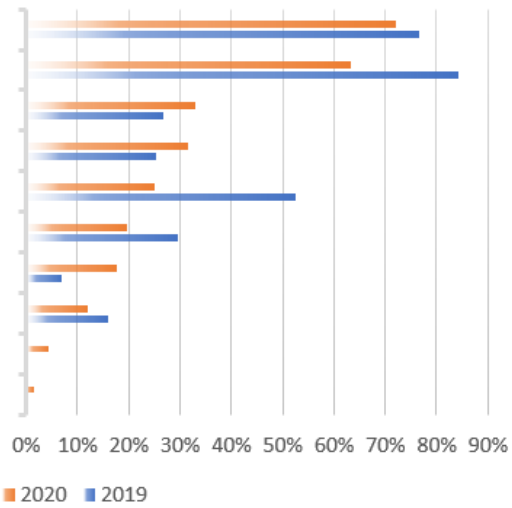

Fig. 1. The structure shift of value orientations in older men and women in Tomsk region, 2019-2020 $(\%)$ 
Source: Data of the sociological survey " Institutions to unlock the untapped resource potential of the older generation in an aging economy" / Tomsk: Tomsk Polytechnic University. LifeLong Wellbeing TPU. - 2020 .-- 93 p.

Figure 1 shows shift from 2019 to 2020 in values priorities, it depicts changes in the core of value attitudes among the population $50+$, the value of socio-cultural interaction increases, and a tendency towards a decrease in the value of material wealth is noticeable (the fall in 2020 by 2019 is almost 2 times).

We could not to talk about the emerging trend, but it is permissible to assert that the outlined reorientation of the $50+$ population in the Tomsk region indicates significant socioeconomic upheavals that will be reflected in the near future on consumer preferences and behavior changes, which will disrupt the structure of the national economy. We have revealed the sociocultural potential of seniors for the development of a creative society that shares the goals of sustainable development. People 50+ can become a source for the future structural transformations of the Russian economy and the human potential 50+ carries hidden reserves of growth and development. External difficulties are pushing Russian society towards social creativity and inclusion. Unfavorable circumstances serve to the search for internal resources for self-development and force to adapt to the new rules of the game.

\section{Conclusions}

1. The ongoing changes affect not only industrial production, but also the sphere of human life and activity, reorienting private investment, consumer preferences and value attitudes. We should talk about the process of the formation of a creative society in the economy of a developed subsystem of the knowledge economy with a negative growth trend in personal material consumption (USA, Germany, Japan).

2. The accumulation of intellectual capital facilitates the replacement of person-hours by machine-hours, routine intellectual labor functions is automated, which stimulates the demand for the acquisition of new knowledge and the development of creative skills. Thus, there is a process of slowing down the pace of material consumption and a growing demand for services, especially in education and health.

3. Restrictive measures introduced in connection with the spread of a new coronavirus infection affect changes in value attitudes in society, shifting the focus towards the growth of priorities for socio-cultural interactions. It is premature to talk about the sustainability of such a trend in Russian society, the case of the Tomsk region cannot indicate All- Russian trends.

4. The development of the Russian economy in conjunction with the goals of sustainable development is possible in the context of "intellectualization" of human potential and the creation of mechanisms for the involvement of traditionally inactive social groups, including the older generation. Hidden reserves of growth lie in the underutilization of the potential of social creation and social inclusion due to the lack of development institutions.

5. Sustainable development of the Russian economy is possible only in the context of restructuring of personal consumption towards a shift towards the prevalence of disposable income towards the consumption of "knowledge-intensive" goods and services. Low incomes of the population create a production demand in the spheres of the food industry and material production (more than $70 \%$ of the direction of household expenditures), which hinders the development of a subsystem of the knowledge-based economy. 


\section{Acknowledgements}

The study was supported by the Russian Science Foundation as part of the research project "Institutions to unlock the untapped resource potential of the older generation in an aging economy" (project No. 19-18-00300).

\section{References}

1. S. M. Busoi, Procedia Economics and Finance, 26, 46 (2015)

2. A. N. Dreval, The European Proceedings of Social \& Behavioural Sciences (EpSBS), 38, 134 (2018)

3. W. Batat, IDEAS Working Paper Series from RePEc Business And Economics (2011)

4. J. Kuczyński, B. Ochalska, Dialectics and Humanism, 4(2), 25 (1977)

5. E.J. Arnould, C.J. Thompson, Journal of Consumer Research, 868 (2005)

6. M. Csikszentmihalyi, Éditions Robert Laffont (2005)

7. D.B. Holt, Journal of Consumer Research, 22(1), 1 (1995)

8. P. Nelson, Journal of Political Economy, 78(2), 311 (1970)

9. C.K. Prahalad, V. Ramaswamy, Journal of Interactive Marketing, 18, 5 (2004)

10. C.J. Thompson, M.Troester, Journal of Consumer Research, 28, 550 (2002)

11. M. Moehlmann, Journal of Consumer Behaviour, 14(3), 193 (2015)

12. T. Schmidt, S. Vosen, Ruhr Economic Paper, 155 (2009)

13. M.Gil, J. J Perez, A. J. Sanchez Fuentes, A. Urtasun, SSRN Electronic Journal, 1842 (2018)

14. BJ Pine, JH Gilmore, Harvard Business Review, 76(4) (1998)

15. L.F. Barrett, B. Mesquita, K.N. Ochsner, J.J. Gross, Annual Review of Psychology, 58, 373 (2007)

16. I. L. Timonina, Japanese Studies in Russia, 4, 92 (2018)

17. O.I. Fedorova, T.N. Sirovatkina, Vestnik OSU, 13(149), 388 (2012)

18. N.G. Kovaleva, Social studies, 7, 73 (2001) 